\title{
Field Teaching Practicum Problems Experienced by Science and Mathematics Students and Their Attitudes toward Teaching Profession at Najran University
}

\author{
Yahea Ali Fagihi ${ }^{1, *}$, Hassan Shawky Aly ${ }^{2}$ \\ ${ }^{1}$ Curricula \& Teaching Methods of Science, College of Education, Najran University \\ ${ }^{2}$ Curricula \& Teaching Methods of Mathematics, College of Education, Najran University and Minia University \\ *Corresponding author: yahyafaqihi@ hotmail.com
}

\begin{abstract}
The current study aims to investigate the problems of field practicum at the College of Science and Arts at Najran University from science and mathematics students' perspective and to measure their attitudes toward teaching profession. To achieve this aim, a questionnaire of field teaching practicum problems and a scale of student teachers' attitudes toward teaching profession were prepared. The sample consisted of (123) male and female students of science and mathematics departments enrolled in the field practicum course. The study concluded that during field training, students face (21) problems distributed to four domains: cooperating school administration, academic supervisor, teaching skills of trainee student, and the trainee student's personality. There is a statistically significant difference in the problems of cooperating school administration and teaching skills due to gender variable in favor of female students. There is a statistically significant difference in the problems of cooperating school administration due to specialization variable in favor of mathematics students. There is no statistically significant difference due to specialization variable in the other domains and problems as a whole. There is no statistically significant difference in the problems facing students due to the cumulative average variable. The sample responses to the attitude scale toward teaching profession reach an average agreement of (3.75), which indicates that the sample has positive attitudes toward teaching profession. There is no statistically significant difference on the attitude scale toward teaching profession as a whole or its domains due to gender or cumulative average variables. There is a statistically significant difference in the responses of the sample to the attitude scale toward teaching profession due to specialization variable in favor of science specialization.
\end{abstract}

Keywords: practicum problems, attitude toward teaching profession

Cite This Article: Yahea Ali Fagihi, and Hassan Shawky Aly, "Field Teaching Practicum Problems Experienced by Science and Mathematics Students and Their Attitudes toward Teaching Profession at Najran University." American Journal of Educational Research, vol. 6, no. 3 (2018): 201-209. doi: 10.12691/education-6-3-7.

\section{Introduction}

The teaching practicum stage (field training) is an important turning point in the life of the student teacher and a very important aspect of the Colleges of Education programs. The preparation of the teacher is accomplished through a theoretical study of the philosophy of education, learning theories, teaching strategies, the practice of this philosophy and theories, and the application of strategies in the Education environment. The teacher preparation program is not restricted to the cognitive aspects of the field of specialization, but the student must acquire a lot of educational knowledge and skills. The teaching practicum is one of the most important components of the educational course in various colleges of education as it is considered a real opportunity for the student teachers to experience the educational process, and to train them on different teaching skills that they need to improve their performance and develop their attitudes toward teaching profession [1].

The teaching practicum achieves many goals such as inculcating the desired behavioral attitudes of ethics and professional ethics, and developing the attitudes toward the teaching profession. In modern education, the teacher's dedication is largely relevant to his attitude toward teaching profession and this dedication is directly proportional to his positive attitudes toward it. The attitudes are considered acquired factors in the human behavior, so the educational institutions are concerned with graduating a generation provided with proper attitudes. Educators emphasize that learning that leads to the formation of desired attitudes among students is more useful than learning that is based on memorizing facts and information. While cognitive experiences are forgettable, the influence of attitudes lasts [2].

The teaching practicum is considered as a window to practical life and it develops the principles, foundations and theories of teaching of the student teacher in the form 
of realistic behavioral practices in the training schools. It represents a link between the educational preparation and the academic preparation of the student teacher. Wood [3] points out that teaching practicum program contributes to giving students a deeper understanding of the class teaching process where students implement their theoretical studies practically.

As the universities are responsible for preparing specialized cadres in various fields, the need arises to study the programs of these universities, especially those relevant to the colleges of educational sciences concerned with the preparation of pre-service teachers. These colleges aim to provide students with the knowledge and skills necessary to build their future professional personality. In order to sustain this development, there have to be effective training programs capable of upgrading the teacher in order to maintain the highest degree of excellence and proficiency

Owing to the importance of the field implementation phase in the teachers preparation programs, the researchers in Saudi Arabia and many Arab and foreign countries showed great interest in the problems that face the teaching practicum students so as to guide these programs and help them improve and develop this important phase of the preparation programs by avoiding problems or finding appropriate solutions to them. Some of these studies are Alsaieda and Mahasnah [4], Al-Mutari [5], Musleh [6], Al-Abd El-Munaem [7], Uthman [8], Al-Buhairi [9], Salamah [10], Abu Latifa and Essa [11], Mansour and Al-Harbi [12], and Abulair et al. [13].

In the light of literature review, there are some problems that face students during the practical implementation of the teaching practicum course including problems relevant to school schedules, place of training, students, faculty members, school administration, and the cooperating teacher. The current study aims to identify the problems that face students of the science and mathematics departments at the University of Najran during the practical field application. The attitudes toward teaching profession represent great importance in determining the degree of acceptance and rejection of the different aspects of the teaching profession. Accordingly, it is important to identify the attitudes of the students toward teaching profession to promote and support the desired positive attitudes and change the undesired negative attitudes as the success of a teacher depends on his positive attitude toward teaching. These attitudes affect his/her students emotionally, socially and mentally, so it is necessary to find out the attitudes of teachers to identify the positive and negative aspects of these attitudes [14]. Attitudes, as defined by Zahran [15] represent the current personal stance toward certain issues based on experiences acquired through learning from different situations in his or her environment. This stance takes the form of acceptance or rejection, and appears during the verbal or practical behavior of the individual.

The specialists stress the importance of forming positive attitudes among students of the College of Education toward teaching profession and developing them during their preparation phase. Some believe that possessing these attitudes should be considered as a requirement for practicing the teaching profession. Al-Kandari and Faraj [16] pointed out that the teacher's possession of positive attitudes toward teaching profession is a requirement for getting a license to practice this profession.

The process of forming or acquiring attitudes toward teaching profession or any other psychological attitudes is a dynamic process, which is the result of complex interactions between the individual and the physical and social environment features. Through the various channels of this interaction, psychological attitudes can be acquired. According to Ali [17], psychological attitudes include three components:

- The cognitive component: the individual's cognitive responses and beliefs.

- The affective (emotional) component: the emotional nature and tendency of the individual that affect the response to accept or reject the attitude.

- The behavioral (practical) component: It appears in practical responses, which is the individual's inclination or tendency to adopt a certain behavior according to specific patterns in a particular subject or stance.

The positive attitudes of the teacher play a vital role in his/ her professional success and academic progress, and in forming the teacher who is aware of his/her responsibilities and duties, and seeks to improve his/her performance. The interest in the preparation and training of teachers before and during service should be accompanied by full knowledge of their attitudes toward teaching profession and its relevant issues. It is one of the most important aspects of the social interest in the educational process, since the teacher is the core of the educational process. If the teacher is well prepared, education will become better and this, in turn, leads to the welfare of the society [18].

Accordingly, many researchers have shown interest in studying the attitudes of teachers and student teachers toward teaching profession, such as Ahmad [19], Abdul Mutalip [20], Hamada [21], Muhammad [22], Balabel [23], Tabshi and Alshayeb [24], Al-Mujeedil \& Al-Shirea' [25], and Abdul Qadir [26]. The results of these studies showed that there are no differences in the attitude toward teaching profession due to specialization. The gender variable has an effect on the attitudes of the student teachers toward teaching profession and these differences are in favor for the female students. In addition, male student teachers have positive attitudes toward teaching profession.

Consequently, the need to identify the attitudes of the students toward teaching profession is an ongoing need as it is very relevant to the quality and size of the problems that face the student teacher during the teaching practicum phase. Here comes the importance of this study which deals with two effective aspects of shaping the future teacher. The problems that face the student teacher have an effect on the formation of his/her attitudes toward the teaching profession. Moreover, the teachers' initial attitudes toward education profession contribute to determining the style of interaction with the problems that happen by getting involved in the educational teaching profession.

\subsection{Statement of the Problem}

It is observed through researchers' supervision and follow-up on the teaching practicum students that field practical training faces many problems that may reduce 
the effectiveness and quality of its outputs. The various academic, organizational, financial, and student problems may have a negative effect on students' attitudes toward teaching profession. The current study aims to identify field practicum problems and the factors affecting the future attitudes of the students toward teaching profession. Consequently, it contributes to developing the educational process and improving the quality of future teachers.

\subsection{Questions}

The current research problem is determined by the following main question: What are the field practicum problems that face students of science and mathematics at Najran University and their attitudes toward teaching profession?

From the main question, the following sub-questions are derived:

1. What are the problems that face students of science and mathematics at Najran University during the field practicum from their point of view?

2. Do the sample responses to the questionnaire of field practicum problems differ due to gender variable (male/ female students)?

3. Do the sample responses to the questionnaire of field practicum problems differ due to the specialization variable (science/ mathematics)?

4. Do the sample responses to the questionnaire of field practicum problems differ due to cumulative average variable (less than very good/ very good and more)?

5. What are the attitudes of the students of science and mathematics at Najran University toward teaching profession?

6. Do the sample responses to the attitude scale toward teaching profession differ due to gender variable (male/ female students)?

7. Do the sample responses to the attitude scale toward teaching profession differ due to the specialization variable (science / mathematics)?

8. Do the sample responses to the attitude scale toward teaching profession differ due to the cumulative average variable (less than very good / very good and more)?

\subsection{Objectives}

The current study aims to:

- Identify the problems that face students of science and mathematics specializations at Najran University during the field practicum from their point of view.

- Identify the different responses of the study sample to the problems of the field practicum according to the variables: gender (male/female students), specialization (science/mathematics), and cumulative average (less than very good/ very good and more).

- Measure the attitudes of students of science and mathematics at Najran University toward teaching profession.

- Identify the extent of students' different attitudes toward teaching profession in the light of their responses to the utilized scale according to the gender variable (male/female students), specialization (science-mathematics) and cumulative average (less than very good/ very good and more).

\subsection{Significance}

The current study represents a step in the development of field training through monitoring the problems facing field training students and proposing recommendations to solve them; thus contribute to the progress and development of the educational process. It also helps identify the attitudes of male/female students of science and mathematics at the Faculty of Science and Arts at Najran University toward the teaching profession, which can explain the reasons for some problems that face field training students.

\subsection{Limitations}

- Students of the science and mathematics departments at the Faculty of Science and Arts enrolled in the teaching practicum course.

- Second semester of the academic year 2016/2017.

\subsection{Procedural Terminology}

Field teaching practicum: It can be defined as the training course studied by the male/female student of the Faculty of Science and Arts and supervised by the College of Education. Throughout the course, the student practices the teaching process and the relevant activities, skills and teaching tasks for a full semester in a governmental preparatory or secondary school under the supervision of a specialized faculty member in the curricula and teaching methods of the student's specialization.

The attitude toward teaching profession: It is defined as the readiness to join the teaching profession. This readiness takes the form of acceptance or rejection to the profession. It is determined by the total degree achieved by the student in his response to the attitude scale prepared by the researchers for this purpose.

\subsection{Tools}

- The Questionnaire of the field practicum problems facing students of science and mathematics at Najran University from their own point of view.

- The attitude scale of the student teachers toward teaching profession.

\section{Methodology}

The descriptive approach utilized to collect data through the two research tools, analyzing data, finding results, and proposing recommendations that would hopefully lead to the development of teacher preparation programs, in general, and the teaching practicum aspect, in particular.

\section{Procedures}

1. Preparing the questionnaire of field practicum problems from the perspective of science and 
mathematics students at Najran University: Through examining the previous studies that dealt with the problems of the field teaching practicum, the researchers prepared the initial version of the questionnaire, which included (58) problems distributed to four domains relevant to cooperating school administration, academic supervisor, teaching skills, and student teacher.

Validity and reliability

To calculate the validity of the questionnaire, the initial version of the questionnaire was referred to five specialists in the field of curricula and teaching methods. They supervise field training in order to determine how each problem is properly listed under its domain, the properness of the problems formulation, and the validity of the questionnaire to determine the problems that face the male/female students of science and mathematics specializations at Najran University during the field practicum from their point of view. The modifications recommended by the evaluators were done.

In order to calculate the reliability of the questionnaire, it was applied to 40 male and female eight-level science and mathematics students at the Faculty of Science and Arts. The reliability was calculated using alpha coefficient of reliability with value $(0.95)$, i.e. acceptable reliability coefficient.

After verifying the validity and reliability of the questionnaire, the final version (Appendix 1) contains (51) problems distributed to four domains: The cooperating school administration, including (14) problems; The academic supervisor, including (15) problems; The teaching skills of the student teacher, including (13) problems; The personality of the trainee student, including (9) problems.

2. Designing the attitude scale toward teaching profession: Through examining the previous studies that dealt with the attitude toward teaching profession, the researchers prepared the initial version of the questionnaire, which included (36) problems distributed to two dimensions: Impressions about teaching profession and compatibility of personal traits and teaching profession.

Validity and reliability

To calculate the validity of the attitude scale toward teaching profession, the initial version of the scale was referred to seven specialists in the field of psychology, curricula and teaching methods at the College of Education, Najran University to determine How each item properly listed under its dimension, the properness of the items formulation, and the validity of the scale to measure the attitude toward teaching profession. The modifications recommended by the evaluators were done.

In order to calculate the reliability of the scale, it was applied to 40 male and female eight-level science and mathematics students at the Faculty of Science and Arts. The reliability was calculated using alpha coefficient of reliability with value (0.89) which is acceptable reliability coefficient.

After verifying the validity and reliability of the scale, the final version (Appendix 2) includes (30) items distributed to two dimensions, as shown in Table 1.

Applying tools: The tools were applied on the research sample in the second semester of the academic year 2016/2017.

Statistical analyses: The following statistical tools were utilized:

- Mean and Standard Deviation of the sample's responses to the two research tools.

- Confidence intervals of the response average where the degree of agreement was determined in the light of the following Table 2 .

- T-test to determine the impact of gender and specialization variables on the responses of the sample.

\section{Results}

To answer of the first question which is: What are the problems that face the female/ male students of science and mathematics at the University of Najran in their performance of the field practicum from their point of view? The mean and standard deviation of the responses of the sample to each item of the questionnaire of field practicum problems were calculated. Table 3 shows the results of the analysis of the items which represent a problem from the point of view of the students in each domain:

Table 1. The attitude scale toward teaching profession

\begin{tabular}{|l|c|c|c|}
\hline Dimensions & Positive Items & Negative Items & No. of items \\
\hline Impressions on Teaching Profession & $1-3-4-7-10-13-15$ & $2-5-6-8-9-11-12-14$ & 15 \\
\hline Compatibility of personal traits and teaching profession & $17-19-26-27-28-29-30$ & $16-18-20-21-22-23-24-25$ & 15 \\
\hline Total & 14 & 16 & 30 \\
\hline
\end{tabular}

Table 2. Confidence intervals of the response average

\begin{tabular}{|c|c|c|}
\hline alternative response & Minimum average & Maximum average \\
\hline Strongly agree & 4.2 & 5 \\
\hline Agree & 3.4 & Less than 4.2 \\
\hline Hesitant & 2.6 & Less than 3.4 \\
\hline Disagree & 1.8 & Less than 2.6 \\
\hline Strongly disagree & 1 & Less than 1.8 \\
\hline
\end{tabular}


Table 3. Students' agreement degree to the questionnaire of field practicum problems

\begin{tabular}{|c|c|c|c|c|}
\hline \# & Problem & Mean & $\begin{array}{l}\text { Standard } \\
\text { deviation }\end{array}$ & Response \\
\hline \multirow{4}{*}{ 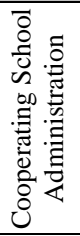 } & Lack of meetings held with teaching practicum students to identify their problems. & 3.93 & 1.56 & agree \\
\hline & $\begin{array}{l}\text { Lack of facilities and resources required by teaching practicum students to carry out their teaching } \\
\text { tasks. }\end{array}$ & 3.67 & 1.63 & agree \\
\hline & Remoteness of school form the residence of the trainees & 3.63 & 1.66 & agree \\
\hline & $\begin{array}{l}\text { The school administration doesn't deal with the problems arising from some of its } \\
\text { students toward the teaching practicum students. }\end{array}$ & 3.56 & 1.66 & agree \\
\hline \multirow{5}{*}{ 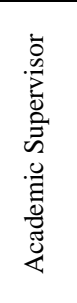 } & $\begin{array}{l}\text { The supervisor uses oral discussion method in supervision without practical } \\
\text { explanation. }\end{array}$ & 3.74 & 1.27 & agree \\
\hline & Lack of visits from the academic supervisor to the trainee students. & 3.60 & 1.24 & agree \\
\hline & $\begin{array}{l}\text { The supervisor concentrates on criticizing the student instead of giving suitable } \\
\text { alternatives. }\end{array}$ & 3.46 & 1.28 & agree \\
\hline & $\begin{array}{l}\text { The supervisor doesn't solve the administrative problems that face the student at the } \\
\text { cooperating school. }\end{array}$ & 3.63 & 1.36 & agree \\
\hline & The supervisor doesn't take into account the opinions and observations of the students. & 3.41 & 1.26 & agree \\
\hline \multirow{7}{*}{ 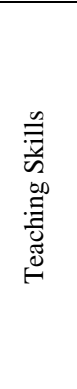 } & Utilizing different teaching methods to teach parts of a lesson. & 3.83 & 0.93 & agree \\
\hline & Taking into account the abilities of the students in the classroom. & 3.83 & 0.87 & agree \\
\hline & $\begin{array}{l}\text { I find difficulty in selecting the appropriate teaching methods for the educational } \\
\text { content. }\end{array}$ & 3.60 & 0.99 & agree \\
\hline & The balancing skill of distributing the time of the period to the lesson components. & 3.60 & 1.01 & agree \\
\hline & $\begin{array}{l}\text { Preparing and writing lessons represent difficulty facing the teaching practicum } \\
\text { students. }\end{array}$ & 3.56 & 1.13 & agree \\
\hline & Preparing more than one lesson daily. & 3.42 & 1.09 & agree \\
\hline & $\begin{array}{l}\text { I don't have enough knowledge of the appropriate teaching skills to deal with the } \\
\text { classroom issues. }\end{array}$ & 3.42 & 1.03 & agree \\
\hline \multirow{5}{*}{ 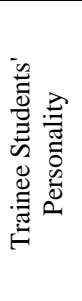 } & $\begin{array}{l}\text { The trainee student feels worried and nervous during the classroom visit of the } \\
\text { supervisor. }\end{array}$ & 3.73 & 0.96 & agree \\
\hline & $\begin{array}{l}\text { The school students consider the student teacher different from their respective class } \\
\text { teacher. }\end{array}$ & 3.62 & 0.97 & agree \\
\hline & The trainee students are not enthusiastic about the teaching profession. & 3.57 & 0.93 & agree \\
\hline & Recurrent of absence of some trainee students from the teaching practicum. & 3.49 & 1.00 & agree \\
\hline & $\begin{array}{l}\text { Weak motivation and encouragement of the trainee students to get them interested in } \\
\text { the teaching practicum. }\end{array}$ & 3.45 & 1.05 & agree \\
\hline
\end{tabular}

Table 3 shows the following:

The cooperating school administration

In this domain, four problems face the male/female students:

- The need of students to know the school administration rules and regulations.

- The need of students to use the physical facilities of the school in carrying out their teaching tasks.

- Many students are expatriates and are in need of a convenient means of transport to reach the schools of application, especially for female students.

- The school administration treats field training students as teachers and not as trainees.

The Academic Supervisor

In this domain, five problems face male/female students due to the big number of schools of application and their distance, in addition to, the big number of students enrolled with the academic supervisor and the lack of teaching experience of students.

The teaching skills of the student teachers

In this domain, five problems face the male/female students due to the lack of experience of the trainee students in dealing with the different teaching situations and classroom management, because the student applies teaching practicum once at the eighth level, which is not enough to give them practical experience in applying the educational methods and distributing the time of the period. This may be due to the lack of interest of the supervisor in training the student on the application of educational methods and how to distribute the time of the period.

\section{The trainee students' personality}

In this domain, five problems face the male/female students due to:

- The course of the teaching practicum is eight teaching hours and has an impact on the rates of students, which may make students worried during the evaluation visits.

- The field training phase represents the end of the university level and the beginning of recruitment and may make students worried.

- Asking students to attend throughout the training period and the entire daily hours and the whole semester.

To answer the second question: Do the sample responses to the questionnaire of field practicum problems differ due to gender variable (male/ female students)? The T-test utilized to determine the impact of the gender variable on the sample responses to the questionnaire domains of field practicum problems. Table 4 shows the results.

In Table 4, there is a statistically significant difference due to gender variable in favor of female students in the problems of the cooperating school administration, teaching skills and problems as a whole. There is no statistically significant difference between male and female students concerning the problems of the academic 
supervisor and the personality of the trainee student. The difference indicator in favor of the female students may be due to the problem they face, especially the expatriates, in getting to the places of schools of application and the difficulty in carrying out regular visits by the female supervisors to schools. It leads to weakness in developing the teaching skills of the female students. This result differs partially from the result of Musleh [6] and Abulair et al. [13].

To answer the third question: Do the sample responses to the questionnaire of field practicum problems differ due to the specialization variable (science/ mathematics)? The T-test was used to identify the impact of specialization variable on the sample responses as shown in Table 5.

Table 5 shows that there is a statistically significant difference due to specialization in the problems of cooperating school administration in favor of mathematics students, while there is no statistically significant difference due to specialization in the other domains and problems as a whole. This means that mathematics students face problems due to school administration more than science students. This may be due to the need of mathematics students for educational aids and school tools because of the nature of abstract mathematics. This result differs from the result of Musleh [6], Al-Buhairi [9], and Mansour \& Al-Harbi [12].

To answer the fourth question: Do the sample responses to the questionnaire of field practicum problems differ due to cumulative average variable (less than very good/ very good and more)? The T-test was used to identify the impact of the cumulative average on the sample responses as shown in Table 6.

Table 4. T-test results of significant difference of the sample responses to the questionnaire of field teaching practicum problems according to gender variable

\begin{tabular}{|c|c|c|c|c|c|c|}
\hline Domain & Gender & Number & Mean & standard deviation & T-value & significance \\
\hline \multirow{2}{*}{ Cooperating school administration } & Male & 31 & 3.04 & 0.91 & \multirow{2}{*}{2.17} & \multirow{2}{*}{ significant at 0.05} \\
\hline & Female & 92 & 3.48 & 0.99 & & \\
\hline \multirow{2}{*}{ Academic supervisor } & Male & 31 & 3.10 & 0.84 & \multirow{2}{*}{1.87} & \multirow{2}{*}{ insignificant at 0.05} \\
\hline & Female & 92 & 3.45 & 0.93 & & \\
\hline \multirow{2}{*}{ The teaching skills of the trainee student } & Male & 31 & 3.12 & 0.74 & \multirow{2}{*}{3.02} & \multirow{2}{*}{ significant at 0.01} \\
\hline & Female & 92 & 3.55 & 0.66 & & \\
\hline \multirow{2}{*}{ The trainee student's personality } & Male & 31 & 3.10 & 0.84 & \multirow{2}{*}{1.87} & \multirow{2}{*}{ insignificant at 0.05} \\
\hline & Female & 92 & 3.45 & 0.93 & & \\
\hline \multirow{2}{*}{ Total } & Male & 31 & 3.09 & 0.67 & \multirow{2}{*}{2.60} & \multirow{2}{*}{ significant at 0.01} \\
\hline & Female & 92 & 3.48 & 0.75 & & \\
\hline
\end{tabular}

Table 5. T-test results of significant differences of the sample responses to the questionnaire of field practicum problems according to specialization

\begin{tabular}{|c|c|c|c|c|c|c|}
\hline Domain & Specialization & No. & Mean & Standard deviation & T-value & Significance \\
\hline \multirow{2}{*}{ Cooperating school administration } & Math & 68 & 3.56 & 1.01 & \multirow{2}{*}{2.36} & \multirow{2}{*}{ significant at 0.05} \\
\hline & Science & 55 & 3.14 & 0.91 & & \\
\hline \multirow{2}{*}{ Academic Supervisor } & Math & 68 & 3.47 & 0.99 & \multirow{2}{*}{1.42} & \multirow{2}{*}{ insignificant at 0.05} \\
\hline & Science & 55 & 3.23 & 0.80 & & \\
\hline \multirow{2}{*}{ The teaching skills of trainee student } & Math & 68 & 3.50 & 0.74 & \multirow{2}{*}{1.01} & \multirow{2}{*}{ insignificant at 0.05} \\
\hline & Science & 55 & 3.37 & 0.66 & & \\
\hline \multirow{2}{*}{ The trainee student's personality } & Math & 68 & 3.47 & 0.99 & \multirow{2}{*}{1.42} & \multirow{2}{*}{ insignificant at 0.05} \\
\hline & Science & 55 & 3.23 & 0.80 & & \\
\hline \multirow{2}{*}{ Total } & Math & 68 & 3.50 & 0.80 & \multirow{2}{*}{1.90} & \multirow{2}{*}{ insignificant at 0.05} \\
\hline & Science & 55 & 3.24 & 0.65 & & \\
\hline
\end{tabular}

Table 6. T-test results of significant differences of the sample responses to the questionnaire of field practicum problems according to cumulative average

\begin{tabular}{|c|c|c|c|c|c|c|}
\hline Domain & cumulative average & No. & Mean & Standard deviation & T-value & Significance \\
\hline \multirow{2}{*}{$\begin{array}{l}\text { Cooperating school } \\
\text { administration }\end{array}$} & Less than very good & 66 & 3.38 & 1.07 & \multirow{2}{*}{0.11} & \multirow{2}{*}{ insignificant at 0.05} \\
\hline & Very good and more & 57 & 3.36 & 0.88 & & \\
\hline \multirow{2}{*}{ Academic supervisor } & Less than very good & 66 & 3.45 & 0.92 & \multirow{2}{*}{1.16} & \multirow{2}{*}{ insignificant at 0.05} \\
\hline & Very good and more & 57 & 3.26 & 0.91 & & \\
\hline \multirow{2}{*}{$\begin{array}{l}\text { The teaching skills of the } \\
\text { trainee student }\end{array}$} & Less than very good & 66 & 3.47 & 0.59 & \multirow[t]{2}{*}{.42} & \multirow{2}{*}{ insignificant at 0.05} \\
\hline & Very good and more & 57 & 3.41 & 0.82 & & \\
\hline \multirow{2}{*}{$\begin{array}{l}\text { The trainee student's } \\
\text { personality }\end{array}$} & Less than very good & 66 & 3.45 & 0.92 & \multirow{2}{*}{1.16} & \multirow{2}{*}{ insignificant at 0.05} \\
\hline & Very good and more & 57 & 3.26 & 0.91 & & \\
\hline \multirow{2}{*}{ Total } & Less than very good & 66 & 3.44 & 0.76 & \multirow{2}{*}{0.85} & \multirow{2}{*}{ insignificant at 0.05} \\
\hline & Very good and more & 57 & 3.32 & 0.73 & & \\
\hline
\end{tabular}


Table 6 shows that there is no statistically significant difference in the cumulative average variable in the problems of the cooperating school administration and the problems domains as a whole. This may be due to ongoing follow-up by the supervisors and the school administration on the trainees, or because the students with "very good and more" and "less than very good" feel the responsibility entrusted to them in the implementation of the course of the teaching practicum. This result is consistent with the results of Musleh [6] and Mansour and Al-Harbi [12].

To answer the fifth question, what are the attitudes of the students of science and mathematics at Najran University toward teaching profession? The mean, standard deviation, and degree of agreement of the students' responses were calculated on each dimension of the attitude scale toward teaching profession and the scale as a whole. Table 7 shows the results:

Table 7 shows that the responses of the sample of the study on the attitude scale toward teaching profession and its dimensions are with agreement average of (3.75). It indicates that there is a positive attitude among the participants toward the teaching profession. This is because field training is the final stage of university study and the start of getting recruited to improve their financial and social conditions. This is consistent with the results of Muhammad [22], Tabshi \& Al-Shayeb [24] and Al-Mujeedil \& Al-Shirea' [25].

To answer the sixth question, 6. Do the sample responses to the attitude scale toward teaching profession differ due to gender variable (male/ female students)? The T-test was used to identify the impact of the gender variable on the sample responses to the attitude scale toward teaching profession as shown in Table 8.
Table 8 shows that there is no statistically significant difference due to gender variable in the attitude scale toward teaching profession as a whole or its fields. This means that the attitudes of male/female students toward teaching profession are close regardless of gender. It may be due to having the same desire to graduate and join teaching profession to improve their financial and social conditions. This result is inconsistent with the result of Al-Mujeedil \& Al-Shirea' [25], which showed differences in the attitude in favor of female students.

To answer the seventh question, do the sample responses to the attitude scale toward teaching profession differ due to the specialization variable (science/mathematics)? The T-test was used to identify the impact of the specialization variable on the sample responses to the attitude scale toward teaching profession and Table 9 shows the results.

Table 9 shows that there is a statistically significant difference of the specialization variable in the sample responses to the attitude scale toward teaching profession in favor of science specialization. This means that the students' attitudes of science specialization are more positive than those of math students. This may be due to the nature of science and the availability of labs to teach science in most schools. This result is inconsistent with Abdul Mutalip [20] which showed no difference in the attitude due to specialization.

To answer the eighth question, do the sample responses to the attitude scale toward teaching profession vary according to the cumulative average variable (less than very good / very good and more). The T-test was used to determine the impact of the specialization variable on the sample responses to the attitude scale toward teaching profession. Table 10 shows the results.

Table 7. Students' degree of agreement on the attitude scale toward teaching profession

\begin{tabular}{|l|c|c|c|}
\hline Dimension & Mean & Standard deviation & 0.47 \\
\hline Impressions on teaching profession & 3.66 & 0.60 & Agree \\
\hline Compatibility of personal traits and teaching profession & 3.83 & 3.75 & 0.49 \\
\hline Attitude scale as a whole & Agree & Agree \\
\hline
\end{tabular}

Table 8. T-test results of significant difference of the sample responses to the attitude scale according to gender variable

\begin{tabular}{|c|c|c|c|c|c|c|}
\hline Dimension & Gender & No. & Mean & Standard deviation & T-value & Significance \\
\hline \multirow{2}{*}{ Impressions on teaching profession } & Male & 31 & 3.69 & 0.55 & \multirow{2}{*}{0.39} & \multirow{2}{*}{ Insignificant at 0.05} \\
\hline & Female & 92 & 3.65 & 0.44 & & \\
\hline \multirow{2}{*}{ Compatibility of personal traits and teaching profession } & Male & 31 & 3.82 & 0.67 & \multirow{2}{*}{0.03} & \multirow{2}{*}{ Insignificant at 0.05} \\
\hline & Female & 92 & 3.83 & 0.57 & & \\
\hline \multirow{2}{*}{ Attitude scale as a whole } & Female & 31 & 3.76 & 0.54 & \multirow{2}{*}{0.17} & \multirow{2}{*}{ Insignificant at 0.05} \\
\hline & Male & 92 & 3.74 & 0.47 & & \\
\hline
\end{tabular}

Table 9. T-test of significant difference of the sample responses to the attitude scale toward teaching profession according to specialization

\begin{tabular}{|c|c|c|c|c|c|c|}
\hline Dimension & specialization & No. & Mean & Standard deviation & T-value & Significance \\
\hline \multirow{2}{*}{ Impressions on teaching profession } & Math & 68 & 3.59 & 0.47 & \multirow{2}{*}{1.80} & \multirow{2}{*}{ Insignificant at 0.05} \\
\hline & Science & 55 & 3.74 & 0.45 & & \\
\hline \multirow{2}{*}{ Compatibility of personal traits and teaching profession } & Math & 68 & 3.73 & 0.59 & \multirow{2}{*}{2.06} & \multirow{2}{*}{ Insignificant at 0.05} \\
\hline & Science & 55 & 3.95 & 0.59 & & \\
\hline \multirow{2}{*}{ Attitude scale as a whole } & Math & 68 & 3.66 & 0.47 & \multirow{2}{*}{2.10} & \multirow{2}{*}{ significant at 0.05} \\
\hline & Science & 55 & 3.84 & 0.49 & & \\
\hline
\end{tabular}


Table 10. T-test results of significant difference in the sample responses to the attitude scale toward teaching profession according to the cumulative average

\begin{tabular}{|c|c|c|c|c|c|c|}
\hline Dimension & Cumulative Average & No. & Mean & Standard Deviation & T-value & Significance \\
\hline \multirow{2}{*}{ Impressions on teaching profession } & Less than very good & 66 & 3.64 & 0.46 & \multirow{2}{*}{0.46} & \multirow{2}{*}{ Insignificant at 0.05} \\
\hline & Very good and more & 57 & 3.68 & 0.48 & & \\
\hline \multirow{2}{*}{$\begin{array}{l}\text { Compatibility of personal traits and } \\
\text { teaching profession }\end{array}$} & Less than very good & 66 & 3.82 & 0.52 & \multirow{2}{*}{0.13} & \multirow{2}{*}{ Insignificant at 0.05} \\
\hline & Very good and more & 57 & 3.83 & 0.69 & & \\
\hline \multirow{2}{*}{ Attitude scale as a whole } & Less than very good & 66 & 3.73 & 0.44 & \multirow{2}{*}{0.31} & \multirow{2}{*}{ Insignificant at 0.05} \\
\hline & Very good and more & 57 & 3.76 & 0.56 & & \\
\hline
\end{tabular}

Table 10 shows that there is no statistically significant difference in the Cumulative Average variable in the sample responses to the attitude scale toward teaching profession and its fields. This may be due to the fact that students with rates "very good and more" and "less than very good" have the same attitude toward teaching profession and the desire to graduate and join teaching profession to improve their financial and social conditions.

\section{Recommendations and Future Studies}

\subsection{Recommendations}

- Increase the number of the cooperating school administration meetings with the teaching practicum students to identify their problems.

- The cooperating school administration should render facilities and provide the resources required for the teaching practicum students to carry out their teaching tasks.

- Choose the application schools near the residence of the trainee students as much as possible.

- The school administration should address some of the problems arise by some students toward the teaching practicum students.

- The supervisor should use practical explanation and supervision without oral discussion.

- The academic supervisor should increase visits to the trainee student.

- The supervisor should provide feedback to students and give appropriate alternatives.

- The supervisor should solve the administrative problems that face the student in the cooperating school.

- The supervisor should take into account the opinions and observations of the students.

- Students should be trained on:

a. Preparing and writing lessons.

b. Using different teaching methods to implement parts of a lesson

c. Taking into account the different abilities of students in the classroom.

d. How to choose appropriate teaching strategies for the educational content.

e. The skill of balancing the distribution of the period's time on the elements of the lesson.

f. Preparing and writing lessons.

g. Classroom management.

- Spread self-confidence among trainee students and remove anxiety and tension when the supervisor visits them in the classroom.
- Reinforce motivation and positive attitude of the trainee students toward the teaching profession.

- Activate the university regulations and rules to reduce the recurrence of the absence of some trainee students from the teaching practicum.

- Encourage and stimulate trainee students to get interested in the teaching practicum.

- Hold a training course for the teaching practicum supervisors on contact and communication.

\subsection{Future Studies}

- Conducting a study to investigate the problems of field training from the viewpoint of the faculty members.

- A proposed program to train students on how to solve some of the problems they face in the field training and its impact on their attitudes toward teaching profession.

- A proposed program to train the student teacher on the skills of lessons implementation and its impact on his/her teaching performance in the field training.

\section{Fund}

This paper is funded by Deanship of Scientific Research at Najran University (NU/SHED/15/189)

\section{References}

[1] Al-Attab, N. (2004). Effectiveness of educational program for the teaching practicum in the teaching performance of the student teacher and his/her attitudes toward teaching profession (in Arabic). A research presented in the $16^{\text {th }}$ scientific conference: The teacher's formation, The Egyptian Association for curricula and teaching methods, Cairo. July.

[2] Al-Makhzomi, M. N. (2007). The impact of studying at the College of Educational Sciences at Alzarqaa Private University on the attitudes of students of the Class-Teacher department toward teaching profession (in Arabic). Faculty of Education Journal, 74, 457-482.

[3] Wood, K. (2000). The Experience and Learning to Teach: Changing Student Teacher Ways of Understanding Teaching. Teaching and Teacher Education, 32 (1), 75-93.

[4] Alsaieda, M. A. \& Mahasnah, O. M. (2015). The problems facing the Professional Education students at Al Balqaa Technological University during the field training (in Arabic). The Educational Sciences Journal, 42 (1).

[5] Al-Mutari, H. M. K.Q. (2013). Obstacles facing the teaching practicum program at the College of Basic Education in Kuwait and ways of resolving them (in Arabic). Master thesis, Oman Arabic University. 
[6] Musleh, M. M. A. (2013). The problems facing the teaching practicum students at Al-Quds Open University, Bait Sahour studying center, in the practical application of the teaching practicum course (in Arabic). Al-Quds Open University for the Educational and Psychological Studies and Research, 1 (3), 47-82.

[7] Al-Abd El-Munaem, F. M. (2012). The administrative obstacles facing the female student teacher at the College of Science and Human Studies in Huriamalaa during teaching practicum (in Arabic). Faculty of Education Journal, 12, 77-160.

[8] Uthman, A. A. H. (2012). Teaching practicum problems from the viewpoint of the student teacher at the College of Education, Khartoum University (In Arabic). Educational Sciences Journal, $12,79-112$

[9] Al-Buhairi, M. B. M. (2011). The problems facing student teachers (shari'a sciences) in the training course and their relation with some variables (in Arabic). Faculty of Education Journal, 35(2), 165-219.

[10] Salamah, A. M. (2011). Impact degree of using some ecorrespondence in solving the problems of teaching practicum among College of Education students and their attitudes toward it (in Arabic). Information Studies. (11), 85-110.

[11] Abu Latifa, R. F. \& Issa, A. S. (2011). The problems facing teaching practicum at the University of Jordan (in Arabic). Educational Sciences Studies, 38 (2), 2224-2236.

[12] Mansour, A. N. O. \& Al-Harbi, A. T. (2011). The problems facing the student teachers at the College of Education at Ha'il University during the application of the teaching practicum (in Arabic). Education and Psychology Mission, 36, 179-214.

[13] Abulair, N. S. M., Al-ziydat, A. H. Alrahmania, A. A. \& Ubaidat, O. A. (2011). The problems of field training of Special Education students at Al-Balqaa Technological University and their relation with some variables (in Arabic). Educational Sciences Studies, 38, 1919-1930.

[14] Al-Rashed, A. M. (2003). The attitudes of the Colleges of Education students in Saudi Arabia toward teaching profession and their relation to some variables (in Arabic). King Saud University Journal, 15, 1-57.

[15] Zahran, H. A. (1986). Social Psychology (in Arabic). Cairo: Dar Al Kotob.

[16] Al-Kandari, J. \& Faraj, H. N. (2001). Getting liscence to practice teaching profession: Futuristic vision to develop the Arabic teacher's level (in Arabic). The Educational Journal, Kuwait University. 15 (58), 13-54.

[17] Ali, M. H. (2002) .The effectiveness of using the internet in providing the students of the College of Education in Nizwa with the school Mathematics (in Arabic).The Social and Educational Studies, 8(4), 189-234.

[18] Bekheet, M. A. \& El-Ramadi, N. A. (2003). Estimating the attitudes of the female student teachers and kindergartens teachers toward teaching profession in light of some variables (in Arabic). Child and development Journal, 11, 71-100.

[19] Ahmad, A. M. A. (2015). Effectiveness of a program in light of total quality criteria to improve teaching performance and attitude toward teaching profession of the technical education students at the college of Quality Education (in Arabic). The Educational Journal, 40, 1-50.

[20] Abdul Mutalip, A. A. (2014). The attitude toward teaching profession and its relation to psychological alienation and academic achievement among a sample of female students at the College of Basic Education in Kuwait (in Arabic). The Arab Peninsula and Gulf studies, Kuwait, 40 (155), 51-105.

[21] Hamada, M. M. M. (2014). An educational program in teaching practicum based on Home Economics skills and measuring its effectiveness in evaluating teaching profession and attitude toward it among Education students, Helwan University (in Arabic). Journal of Math Education, 17(6), 235-319.

[22] Muhammed, M. A. H. (2014). The effectiveness of a proposed training program for teaching practicum based on active learning strategies in developing teaching methods and attitude toward profession among female student teachers at Damam University in light of total quality criteria (in Arabic).The Educational Journal, 36, 205-271.

[23] Balabel, M. R. M. (2013). Effectiveness of a proposed program based on mini-teaching philosophy in developing the professional performance and attitude toward the profession of Philosophy teachers at secondary stage (in Arabic). Arabic studies in Education and Psychology. 36 (3), 12-64.

[24] Tabshi, B. \& Al-Shayeb, M. A. (2013). Measuring the attitude toward teaching profession of primary stage teachers in light of the new educational reform in Algeria, (in Arabic). Pilot field study in the city of Warqala, Human and Social Sciences Journal, 13, 79-110.

[25] Al-Mujeedil, A. A. \& Al-Shirea', S. (2012). The attitudes of the College of education students toward teaching profession, a comparative field study between the College of Education, Kuwait University and the College of Education in Alhasaka, Furat University (in Arabic). Damascus University Journal, 28 (4).

[26] Abdul Qadir, M. H. A. (2011). A proposed program based on Self-Study to develop some teaching skills and attitude toward teaching profession of the Arabic student teachers (in Arabic). The Educational Journal, 29, 263-330. 